\title{
LITERATION WORKSHOP FOR PARENTS ABOUT THE HAZARD OF COVID-19 AND ITS EFFECTS ON THE MIND AND MENTAL PATTERN OF CHILDREN
}

\author{
WORKSHOP LITERASI KEBAHASAAN UNTUK ORANGTUA TENTANG \\ BAHAYA COVID-19 DAN PENGARUHNYA PADA POLA PIKIR DAN MENTAL ANAK
}

\author{
Emil Septia ${ }^{{ }^{*}}$, Aruna Laila ${ }^{2}$, Wahyudi Rahmat ${ }^{3}$ \\ ${ }^{1,2,3}$ STKIP PGRI Sumatera Barat \\ *E-mail: Email paradise@yahoo.co.id, $\frac{\text { ªruna@stkip-pgri-sumbar.ac.id, }}{{ }^{3} \text { wahyudirahmat24@gmail.com }}$
}

\begin{abstract}
Literacy is very important for parents during a pandemic like today. Parental policy in observing information is highly demanded to understand whether the news obtained actually happened or was just a lie. Knowledge to understand related information with covid-19 really helps parents to organize the mindset and mental patterns of children. Because the information that is growing related to Covid-19 is very damaging to the mind and mental health of children. This happens because the child indirectly hears the danger of Covid-19 from people who are there surroundings, as well as from electronic media so. As a result, the child will feel afraid, because it is not accompanied by a clear explanation to the child about what he hears. For this reason, parental knowledge literacy plays a very important role in the development of children's thinking and mental patterns. The results of this workshop can be seen that the importance of linguistic literacy that needs to be known and controlled by the community, especially parents, to avoid the dangers of the Covid-19 outbreak and can affect the formation of children's thinking and mental patterns.
\end{abstract}

Keywords: literacy; parents; covid-19; mindset; mentally

\begin{abstract}
ABSTRAK
Literasi merupakan sesuatu yang sangat penting bagi orangtua pada masa pandemi seperti saat sekarang ini. Kebijakan orangtua dalam mencermati informasi sangat dituntut untuk memahami apakah berita yang didapat benar-benar terjadi atau hanya berita bohong belaka. Pengetahuan untuk memahami informasi berhubungan

dengan covid-19 sangat membantu orangtua untuk menata pola piker dan mental anak. Kerena informasi yang kian berkembang berhubungan dengan covid-19 sangat merusak pikiran dan mental anak secara diam-diam. Hal ini terjadi karena sang anak secara tidak langsung mendengar bahaya covid-19 dari orang-orang yang ada di

sekitarnya, serta dari media elektronik sehingga. Akibatnya anak akan merasa takut, karena tidak diiring dengan penjelasan yang jelas kepada anak tentang apa yang didengarnya. Untuk itulah literasi pengetahuan orangtua sangat berperan dalam perkembangan pola pikir dan mental anak. hasil workshop ini dapat dilihat bahwa pentingnnya literasi kebahasaan yang perlu diketahui dan dikuasi oleh masyarakat, khususnya orang tua untuk terhindar dari bahaya wabah Covid-19 serta dapat berpengaruh pada pembentukan pola pikir dan mental anak-anak.
\end{abstract}

Kata kunci: literasi; orang tua; covid-19; pola pikir; mental 


\section{Rangkiang: Lurnal Pengabdian Pada Masyarakat UPSM STKIP PGR/ Sumatera Barat}

ISSN: (2721-2688) Vol. 2 No. 2 (Desember 2020): 49 - 59

\section{PENDAHULUAN}

Pada awal tahun 2020, Indonesia digemparkan oleh wabah mematikan yaitu corona. Hingga saat ini virus corona masih menyebar di Indonesia sementara vaksin virus corona belum ditemukan. Karena itu masyarakat Indonesia masih dihantui oleh wabah mematikan ini. Walaupun wabah mematikan masih ada dilingkungan skekitar namum masyaratak Indonnesia harus menjalankan aktivitasnya masing-masing baik dewasa maupun anak-anak. Para orangtua melaksanakan aktivitas di luar rumah untuk memenuhi kebutuhan hidup dan anak-anak harus menjalankan aktivitas belajar, dan bermain. Semua itu dilakukan dengan rasa was-was terhadap lingkungan sekitar. Oleh karena itu, dibutuhkan edukasi mengenai pola penyebaran corona perlu diketahui oleh orangtua dan menjadi tugas orangtua pada saat anak menjalani proses belajar di rumah seperti saat sekarang ini.

Untuk para orang tua ada satu hal yang sangat perlu diperhatikan dan diketahui dalam rangka menghadapi anak selama masa pandemi ini yaitu, orangtua jangan pernah menekankan atau memberitahukan kepada anak bahwa ketika seseorang terinfeksi virus corona maka orang tersebut akan mati. Berdasarkan penelitian yang dilakukan Kurniati terhadap peran orangtua dalam mendampingi anak dimasa pandemic covid-19 bahwa peran orang tua yang muncul selama pandemi covid-19 adalah sebagai pembimbing, pendidik, penjaga, pengembang dan pengawas dan secara spesifik menunjukkan bahwa peran orang tua adalah menjaga dan memastikan anak untuk menerapkan hidup bersih dan sehat, mendampingi anak dalam mengerjakan tugas sekolah, melakukan kegiatan bersama selama di rumah, menciptakan lingkungan yang nyaman untuk anak, menjalin komunikasi yang intens dengan anak. "Jangan berikan informasi bahwa (terinfeksi) corona akan mati. Hal ini tidak layak diberikan pada anak. Kita fokus pada pemahaman virus corona bisa dicegah," kata Psikolog dari Universitas Indonesia Rose Mini Agoes Salim melalui siaran langsung dari kanal BNPB Indonesia, Kamis (19/3/2020). Selain itu Rose menambahkan bahwa, penting bagi orangtua untuk mengajarkan anak mengenai pola hidup sehat dan menjaga kebersihan lingkungan. "Jelaskan pada anak bahwa pola hidup sehat akan membuat daya tahan tubuh lebih sehat sehingga mencegah virus corona," ucapnya.

Sesuai dengan pendapat Graha (dalam Kurniati, 2007) perlakuan 8 orang tua yang selalu memberikan pengertian dan latihan kepada anak tentang kebersihan dan kerapihan, akan dapat menjadikan anak selalu menjaga kebersihan diri. Tidak hanya mengingatkan untuk menjaga pola hidup sehat, peran orang tua juga adalah untuk menjaga dan memastikan agar anak tetap sehat, serta memastikan bahwa anak menerapkan pola hidup sehat dengan benar. Untuk mengantisipasi penularan vius corona para orangtua juga sangat disarankan untuk menjelaskan kepada anak bagaimana langkah-langkah pencegahan agar tidak terinfeksi virus corona tersebut. yaitu dengan mencuci tangan yang baik tidak hanya tangan ditaruh di air keran. Gunakan masker saat anak sakit atau kalau saat di luar rumah. Itu yang harus diberitahukan kepada anak tentang virus corona, bukan menakut-nakuti anak dengan memberikan pernyataan yang membuat pola pikir dan mental anak menurun. Sebagaimana kita ketahui ungkapan yang menyatakan, -Dalam jiwa yang sehat terdapat tubuh yang sehatll. Jiwa yang sehat berarti pikiran yang sehat.

Seringkali kita beranggapan bahwa seseorang itu jatuh sakit karena beban pikirannya terlalu banyak. Sehingga apa yang disampikan kepada sesorang tersebut berkaitan dengan permasalahan kesehatan dan penilaian orang tentang kesehatan berujung kepada berubahnya jiwa atau pikiran seseorang. Pikiran atau jiwa sangat mempengaruhi kesehatan manusia. Kondisi sehat itu apa bila jiwa sehat dan tubuh sehat. Artinya, jiwa dan raga dalam kondisi sehat. Apabila seseorang memiliki banyak pikiran maka dia sedang merasakan suasana jiwa 


\section{Rangkiang: Lurna/ Pengabdian Pada Masyarakat UPSM STKIP PGR/ Sumatera Barat}

ISSN: (2721-2688) Vol. 2 No. 2 (Desember 2020): 49 - 59

tidak tenang, banyak terbebani pikiran. Tubuh yang sehat adalah mental dan spiritual yang normal. Prosesnya sederhana. Pikiran yang tidak tenang melahirkan stres, sebaliknya pikiran yang tenang membuat bahagia dalam menjalani hidup akhirnya selalu ceria. Berpikir satu proses seseorang mempresentasikan perlakuan yang diinginkan atau keinginannya. Proses mempresentasikan diri itu memanipulasi otak terhadap informasi, peristiwa yang dialami seseorang itu.

Untuk itulah sebagai orangtua kita perlu memberikan informasi yang positif kepada anak terkait dengan virus corona yang masih merajalela di Indonesia. Informasi yang diberikan haruslah dapat membangkitkan semangat anak. Sehingga pikiran dan mentalnya tidak terganggu akibat larangan atau pernyataan yang diberikan berhubungan dengan virus corona. Menurut Murtiningsih (2013) menjalin komunikasi yang dilakukan oleh orang tua dan anak menjadi hal penting karena 9 dengan begitu akan mempererat hubungan orang tua dan anak. Melalui komunikasi, maka orangtua akan dapat mengetahui keinginan anak serta orang tua dapat menyampaikan yang diinginkan atau harapan serta dukungan kepada anak. Dengan begitu anak akan semakin terbuka kepada orang tua, begitupun sebaliknya orang tua akan semakin terbuka kepada anaknya, hal tersebut dapat membuat suasana keluarga yang hangat dan nyaman.

Orangtua harus memiliki literasi yang baik, dan mampu pula menyampaikannya kepada anak dengan baik. Orangtua harus dapat menyaring berita yang benar atau tidak. Sebagi orang yang lebih cerdas baik dari segi berpikir maupun mencari literasi orangtua haruslah memikirkan dampak perkataannya kepada pola pikir dan mental anak. Proses berpikir itu memiliki pengaruh terhadap kondisi kesehatan sebab kesehatan merupakan keadaan tubuh, jiwa dan sosial seseorang. Upaya menjadikan tubuh sehat atau menjaga kesehatan satu upaya tidak terjadi gangguan kesehatan. Apa bila anak berpikiran negatif terhadap apa yang disampikan orangtua kepadanya akan mempergaruhi kesehatan fisik anak. Sehingga anak akan melahirkan melahirkan emosi negatif seperti depresi, cemas, kecewa atau perasaan bersalah. Emosi negatif ini menjadi penyebab terjadinya gangguan psikis. Untuk itu berpikir atau pikiran negatif harus dihilangkan, jangan bertahan terlalu lama sehingga mempengaruhi sistem kekebalan tubuh. Apabila kekebalan tubuh menurun viris juga akan cepat masuk, sementara kita harus melawan virus yang sedang mewabah. Untuk itulah diperlukan kecerdasan orangtua unruk menyaring informmasi yang didapatkan terkait virus corona. Agar tubuh anak tetap sehat maka harus memberikan rasa tenang pada pikiran anak. Berpikir positif bermanfaat bagi kesehatan tubuh secara keseluruhan.

Berbagai masalah yang ada dihadapi seseorang secara alami baik sebab masalah yang dihadapi, berbagai tekanan yang diterima menjadi seseorang itu tangguh. Apa bila seseorang itu tangguh menghadapi masalah maka kekuatan tubuhnya telah teruji. Apabila kita mengetahui ketangguhan anak maka informasi yang sembarangan pun tidak maslah diberikan, karena dia memiliki kemampuan menghadapi dan mengatasi masalah. Namun kalau sebaliknya mka anak akan terombang-ambing dalam keadaan stress. 10 Sebagai anggota masyarakat dan sebagai orang yang menghadapi langsung situasi di masa penyebaran virus corona kita dapat melihat beragam dampak yang ditimbulkan oleh virus corona baik bagi orangtua maupun anak. Menurut Dewi 15 April 2020 ada 10 tanda anak tertekan dan kesehatan mentalnya terganggu di masa pandemi corona virus COVID-19. Tidak dapat dipungkiri, pandemi virus Corona COVID-19 membawa perubahan pada berbagai aspek kehidupan. Tak hanya orang dewasa, kondisi psikologis anak pun rentan terganggu oleh situasi yang serba tak menentu saat ini. 


\section{Rangkiang: Lurnal Pengabdian Pada Masyarakat UPSM STKIP PGR/ Sumatera Barat}

ISSN: (2721-2688) Vol. 2 No. 2 (Desember 2020): 49 - 59

Anak-anak diharuskan belajar dari rumah, tidak dapat bermain dan bertemu dengan teman-teman, serta berbagai hal lain harus dilakukan demi menekan penularan infeksi COVID-19 tersebut. Di sisi lain, anak-anak yang tidak begitu mengerti tentang penyakit ini juga bisa tertekan dan terganggu mentalnya akibat rasa ketakutan yang dimilikinya. -Ketakutan dan kecemasan tentang suatu penyakit dapat luar biasa dan menyebabkan emosi yang kuat pada orang dewasa dan anak-anak,\| tulis CDC. Oleh karenanya, para orang tua disarankan untuk mengetahui tanda-tanda stres yang dialami anak akibat pandemi COVID-19 ini.

Tanda Anak Tertekan dan Terganggu Mentalnya Akibat Pandemi COVID-19 Berikut ini beberapa tanda anak tertekan dan terganggu mentalnya saat pandemi COVID-19 menurut The Union Journal: 1. Perilaku Regresif "Secara umum, kita semua akan mengalami sedikit kemunduran dalam fungsi kita selama masa transisi besar ini," kata terapis Noel McDermott. Lebih lanjut ia menjelaskan bahwa anak-anak akan mengalami kemunduran dalam bersikap dan berperilaku seperti kembali mengisap ibu jari, membutuhkan mainan kesayangannya lagi, mengompol, dan sebagainya. "Regresi adalah normal selama periode stres dan ketidakpastian," ujarnya. 2. Perubahan Nafsu Makan "Nafsu makan dan tidur anak sering kali merupakan tanda pertama bahwa segalanya tidak beres," kata Natasha Daniels, seorang spesialis anak muda. "Seringkali seorang anak akan menunjukkan peningkatan tajam atau penurunan nafsu makan." 3. Masalah Tidur Selama tertekan, pola tidur juga dapat berubah. "Perhatikan apakah anak Anda tidur sepanjang hari atau sebaliknya mengalami kesulitan tidur atau tertidur,\| ungkap Daniels. Gangguan tidur sering terjadi pada masa-masa sulit sehingga anak-anak mungkin mengalami masalah tidur, terbangun di malam hari atau berbagai kelainan lainnya. 4. Perubahan suasana hati Perilaku yang harus diketahui terdiri dari ledakan kemarahan, putaran tangisan tak terduga, 11 kesedihan, ketidaksabaran, kehilangan gairah dalam tugas-tugas yang disukai serta berpisah dari yang lain. Anak-anak yang gelisah kemungkinan besar benar-benar merasa lebih gugup, sementara mereka yang bermasalah mungkin memiliki lebih banyak ledakan biasa. "Cari perubahan dalam temperamen atau suasana hati normal mereka dan ingatlah bahwa stres membuat suasana hati Anda lebih normal lagi," kata Craig A. Knippenberg, seorang spesialis serta penulis Wired and Connected: BrainBased Solutions To Ensure Your Child's Social and Emotional Success. 5. Mencari jaminan Dengan anak-anak yang lebih cemas, mereka mungkin mengajukan lebih banyak pertanyaan daripada biasanya. Selain itu, mereka akan lebih sering mencari kepastian bahwa semuanya akan baik-baik saja. Orang tua juga mungkin menemukan bahwa anak-anak mereka lebih gelisah pada waktu tidur dan takut ditinggal sendirian. mungkin menjadi lebih tertarik dan mundur ke kamar mereka untuk menghabiskan lebih banyak waktu untuk teknologi dan telepon. 8. Keluhan somatik Anak-anak mungkin memiliki lebih banyak keluhan sakit kepala, sakit perut, dan lebih sedikit energi. Ini nyata, tetapi kemungkinan bukan karena alasan medis melainkan karena beban pikiran yang mereka miliki. 9. Pemecahan Masalah Anak-anak yang lebih tua maupun remaja mungkin memiliki waktu yang sulit untuk berkonsentrasi pada pekerjaan instruksional atau ragu karena mereka dengan cepat teralihkan. Beberapa di antara mereka mungkin mengalami masalah dengan perhatian, konsentrasi dan pembelajaran baru, yang akan berdampak pada pendidikan mereka. 10. Bertindak berlebihan Selama masa pandemi ini, para orang tua dapat mengamati dan menilai perilaku anak-anak mereka.

Apakah mereka bertindak lebih dari biasanya? Anakanak mungkin mulai mendesak adanya batasan, menunjukkan tingkat permusuhan yang lebih besar, hingga tidak mematuhi arahan atau terlibat dalam lebih banyak perdebatan dengan anggota keluarga. Upaya orangtua 


\section{Rangkiang: Lurnal Pengabdian Pada Masyarakat UPSM STKIP PGR/ Sumatera Barat}

ISSN: (2721-2688) Vol. 2 No. 2 (Desember 2020): 49 - 59

untuk menghindari anak dari pemikiran yang buruk tentang virus corona sangat diperlukan. Orangtua harus menggambarkan kepada anak dalam keseharian bagaiman bersikap saat menghadapi virus corona. Menurut Harususilo orangtua dapat menggunakan kesempatan untuk mengajarkan kepentingan dan tanggung jawab individu dalam sebuah komunitas; bagaimana peran masing-masing dari kita dapat secara langsung berdampak pada virus ini. Salah satu pesan penting dari UNICEF untuk orangtua di saat pandemi ini adalah untuk memperluas ilmu 12 parenting. Hal ini menjadi sorotan UNICEF karena orangtua mengambil peran guru untuk si kecil, dan tanpa pengetahuan yang cukup, maka hal tersebut akan berdampak pada perkembangan dan emosi anak.

Dampak masa pandemi virus corona ini dialami oleh semua anak-anak dan orangtua di Indonesia. Begitu juga dengan orangtua dan anak-anak yang ada di Linnggarjati. Kekhawatiran akan virus corona selalu menghantui para orangtua dan anak, karena semua berita, informasi langsung diterima tanpa mempertimbangkan hal lain. Sarana yang paling utama yang membuat kacau pikiran orangtua dan anak tentang virus corona adalah media literasi baik itu elektronik maupun sarana tulis lainnya dan juga sarana lisan. Karena rasa kalut terhadap virus corona membuat pikiran jernih menjadi kacau sehingga informasi yang diterima tidak dapat dipilahpilah pakah itu benar atau tidak. Untuk itulah pengabdian ini perlu dilakukan sehingga para orangtua dapat meminimalkan bebanpikiran orangtua dan anak tentang bahaya virus corona yang sudah beberapa bulan ini menghantui pikiran siapa saja.

Dengan andanya Workshop Literasi Pengetahuan Orangtua Tentang Bahaya Covid19 Serta Pengaruhnya Pada Pola Pikir dan Mental Anak yang bertempat tinggal di Linggarjati diharapkan para orangtua dapat memanfaatkan literasi yang benar terkait virus corona, sehingga pola pikir dan mental anak tidak terganggu. Karena satu berita yang didapatkan berdasarkan literasi yang salah akan membuat pikiran dan mental berubah. Sesuai dengan pendapat Makhmudah (2016) melalui pendidikan, bagaimana kita menjadi orang-orang yang bermental baik, sehingga keputusan dan perbuatan-perbuatan kita sesuai dengan yang diharapkan dapat menjadi manfaat. Pendidikan dengan memusatkan perhatian pada perubahan kebiasaan sehari-hari yang punyai dampak kebaikan publik.

Proses pendidikan mesti bermuara ke corak kebiasaan bertindak. Pengabdian kepada masyarakat merupakan salah satu dharma atau tugas pokok dari suatu perguruan tinggi termasuk STKIP PGRI Sumbar, di samping dharma pendidikan dan pengajaran serta dharma penelitian. Pelaksanaan dharma pengabdian kepada masyarakat yang dalam realisasinya juga melibatkan dua dharma lainnya. Oleh karena pengabdian kepada masyarakat merupakan salah satu tugas pokok Perguruan Tinggi, maka pelaksanannya harus didukung oleh seluruh sivitas akademika PT tersebut dan dilandasi pemahaman yang benar tentang pengabdian 13 kepada masyarakat sesuai dengan PP 60/99 (BAB III pasal 3 ayat 4) yang menyatakan bahwa $\|$ Pengabdian masyarakat merupakan kegiatan yang memanfaatkan ilmu pengetahuan dalam upaya memberikan sumbangan demi kemajuan masyarakatl. Pengabdian masyarakat yang dilaksanakan sesuai dengan tujuannya adalah Workshop Literasi Kebahasaan untuk Orangtua Tentang Bahaya Covid-19 Serta Pengaruhnya Pada Pola Pikir dan Mental Anak yang bertempat tinggal di Linggarjati.

\section{METODE}

Berdasarkan masalah mitra, maka solusi yang ditawarkan akan dilaksanakan dalam tiga tahap. Pertama, melakukan wawancara dengan anak-anak yang ada di Linggarjati I-IX Kelurahan Parupuak Tabing, Kecamatan Koto Tangah untuk mendapatkan informasi mengenai pola pikir dan mental anak berhubungan dengan pengetahuan tentang covid-19. 
Tahap kedua memberikan materi mengenai literasi pengetahuan orangtua tentang bahaya covid-19. Pemberian materi dipaparkan dengan menggunkan power point dan infocus. Setelah materi literasi pengetahuan orangtua tentang bahaya covid-19 diberikan kepada ibu bapak yang ada diLinggarjati I-IX Kelurahan Parupuak Tabing, Kecamatan Koto Tangah diwawancarai lagi dengan tujuan untuk mengetahui apakah pola pikir dan mentalnya masih sama dengan data yang sebelumnya. Wawancara ini dilakukan lagi dua minggu setelah materi diberikan.

\section{HASIL DAN PEMBAHASAN Isi Hasil dan Pembahasan}

Di masa sekarang, pendidikan literasi gencar dilakukan oleh para praktisi pendidikan untuk mencetak individu yang tidak hanya cerdas dalam bidang akademik, namun juga memiliki pola pikir kritis dan logis. Praktiknya tentu saja tidak harus terpaku pada pembelajaran di sekolah. Orang tua di rumah pun perlu turut andil dalam menanamkan pendidikan literasi pada anak-anak mereka mulai dari usia prasekolah. Tujuan utamanya bukan hanya menekankan pada kemampuan anak untuk membaca atau menulis. Kedua jenis kemampuan tersebut sebenarnya hanya menjadi landasan bagi tujuan yang lebih luas, yakni membentuk generasi yang mampu berpikir kritis dalam menyikapi informasi. Khusus untuk anak usia dini atau prasekolah, pendidikan literasi penting dilakukan karena memiliki banyak manfaat. Berikut adalah beberapa alasan mengapa pendidikan literasi perlu diterapkan sejak dini.

1. Pendidikan literasi untuk anak usia dini bisa dimulai dengan kebiasaan membacakan buku cerita atau dongeng pada anak secara rutin. Meski terkesan seperti kegiatan sederhana, membacakan buku pada anak adalah tahap awal mengenalkan mereka pada dunia literasi.

2. Mengembangkan kemampuan berpikir kritis 20 Tingkat literasi yang tinggi akan berbanding lurus dengan kemampuan seseorang untuk menerima, mengolah, dan menyikapi setiap informasi yang diterimanya. Oleh karena itu, pendidikan literasi yang diterapkan pada anak usia dini berperan sebagai pondasi bagi mereka untuk bisa memiliki kemampuan berpikir kritis dan logis ketika dihadapkan dengan berbagai situasi. Pola pikir kritis diperlukan sebagai investasi yang akan berguna saat anak mulai memasuki dunia masyarakat yang sebenarnya di masa mendatang.

3. Mempersiapkan anak untuk memasuki dunia sekolah Mengenalkan poin-poin utama dalam pendidikan literasi pada anak prasekolah akan membantu mereka mempersiapkan diri saat memasuki dunia sekolah. Perkembangan sosial-emosional, kognitif, bahasa, dan literasi adalah sejumlah aspek penting yang harus dimiliki anak. Aspek-aspek tersebut saling berhubungan satu sama lain dan dapat didukung dengan penerapan pendidikan literasi pada usia dini. Tahapan literasi awal yang meliputi bahasa lisan dan tulisan serta pengetahuan mengenai angka dan huruf menjadi salah satu kunci keberhasilan anak prasekolah dalam membaca. Kemampuan ini akan bisa diandalkan ketika mereka mulai mendapatkan pembelajaran di sekolah.

4. Perkembangan literasi yang baik berkolerasi dengan prestasi akademik Pendidikan literasi yang telah diterapkan sejak dini akan memberikan dampak positif terhadap prestasi akademik seorang anak. Praktik pengenalan literasi awal dengan membacakan buku pada anak terbukti dapat membuat anak lebih sukses dalam bidang akademik. Hal tersebut dikarenakan anak yang telah terbiasa dikenalkan dengan dunia literasi memiliki kemampuan belajar dan berkomunikasi yang lebih baik daripada anak lainnya 
yang belum mendapatkan pengenalan mengenai literasi. Kemampuan akademik tersebut juga ditambahkan dengan kemampuan memecahkan masalah logis seperti dalam pengerjaan soal-soal matematika.

Melihat begitu banyaknya manfaat yang bisa didapatkan anak ketika mereka diberi pendidikan awal tentang literasi sejak usia dini, orang tua sudah sepantasnya menerapkan pendidikan tersebut sedini mungkin. Praktiknya bisa dimulai ketika anak 21 sedang berada dalam tahap eksplorasi atau ketika mereka sudah mulai berbicara dan mulai mengekspresikan bahasa.

Begitu pentingnya literasi yang perlu diterapkan kepada orang tua untuk menyikapai berbagai masalah. Seperti kasus pada masa pandemi wabah COVID-19 ini. Contoh kasus yang sudah terjadi dibeberapa daerah diambil dari beberapa artikel online.

1. Ada kasus tentang orang tua yang melarang anaknya makan sayur karena corona. Cerita ini merupakan kisah nyata yang diperoleh dari beberapa artikel online. Harapannya, bagi pembaca, terutama yang berstatus sebagai orang tua saat ini, dapat memahami serta lebih bijak lagi sebagai sosok panutan bagi anak.

2. Sebenarnya, banyak orang yang taat dengan anjuran di rumah saja yang dikeluarkan pemerintah demi mengurangi penularan virus corona. Mereka sudah mengisolasi diri selama lebih dari tiga bulan (sejak Maret awal) hingga saat ini. Diantara ribuan warga, ada satu warga yang mengaku tidak pernah satu kali pun keluar rumah, bahkan hanya keluar pagar pun tidak pernah. Ibu dan adiknya juga tidak pernah keluar rumah sama sekali. Ayahnya sesekali keluar rumah, hanya untuk membeli beras dan telur untuk makan sehari-hari. Erni (nama warga disamarkan) saat ini tidak berpenghasilan. Ia baru saja lulus sekolah, tetapi tidak bisa bekerja karena corona. Sehari-hari, kebutuhan makan masih ditopang oleh ayahnya, dengan kata lain, semua kendali pembelian barang dipegang oleh ayahnya. Awalnya, semua berjalan baik-baik saja, hingga suatu hari sekitar pertengahan Mei, ia mulai mengeluhkan kondisi kesehatannya. Ia sempat bercerita sudah dua bulan ia hanya mengonsumsi nasi dan telur satu butir untuk sehari. Ia dan ibunya sangat ingin makan sayur, tetapi dilarang membeli oleh ayahnya. Menitip ketika keluar pun, dimarahi. Padahal, salah satu senjata memerangi virus corona adalah dengan mengonsumsi makanan bergizi, di samping rutin mencuci tangan dan menjaga kebersihan diri. Erni mulai lemas, bahkan ia sempat cerita bahwa akibat tidak makan dengan normal itu, ia mengalami konstipasi (sembelit). Fesesnya tidak bisa dikeluarkan, dan menyebabkan kesakitan luar biasa di bagian perut dan anusnya. Waktu itu saya sempat menawarkan bantuan membeli obat melalui layanan pesan antar, tetapi ia 22 takut. Ayahnya tidak memperbolehkan ia dan ibunya membeli apa pun, dengan alasan apa pun. Oleh sebab itulah Erni takut menerima obat dari orang luar. Saya paksakan untuk mau menerima obat konstipasi tersebut. Jika racun tubuh tidak dikeluarkan, apalagi sampai berminggu-minggu, bisa mengancam kesehatan. Saya khawatir kondisinya malah semakin parah, dan tidak menutup kemungkinan ibunya menyusul mengalami hal yang sama. Ketika saya sarankan untuk mencoba mencari pekerjaan, ia mengatakan bahwa telah berkali-kali menolak panggilan kerja karena tidak diizinkan keluar oleh ayahnya. Saya tidak habis pikir, zaman sulit begini malah menolak tawaran kerja ini bagaimana? Akhirnya sebagai jalan tengah, saya katakan padanya untuk tidak sungkan meminta bantuan ke saya apabila kondisinya urgent, termasuk bantuan bahan pangan dan kuota.

Dear orang tua yang terkasih, perlu diketahui bahwa virus corona memang berbahaya bagi anggota keluarga. Namun, apabila Bapak/Ibu membaca kasus di atas, apakah 


\section{Rangkiang: Lurnal Pengabdian Pada Masyarakat UPSM STKIP PGR/ Sumatera Barat}

ISSN: (2721-2688) Vol. 2 No. 2 (Desember 2020): 49 - 59

tindakan yang seperti itu dibenarkan? Tanpa ada maksud menggurui, alangkah baiknya jangan sampai terjadi kejadian seperti teman saya di lain waktu dan tempat. Kalau ceritanya begitu, bisa-bisa bukan mati karena corona, tetapi mati karena faktor lain, dan parahnya faktor kekonyolan akibat terlalu takut dengan virus corona.

(https://www.kompasiana.com/melisatrist/5ed4b042d541df1329728b02/dearorang-tuajangan-salah-kaprah-dengan-virus-corona?page=all

Imbauan untuk tetap tinggal di rumah bukan berarti tidak boleh keluar rumah sama sekali, bahkan sampai mengorbankan kesehatan. Bijaksanalah dalam menerima informasi dari media, mainkan logika, serta buatlah rencana kehidupan untuk beberapa bulan ke depan adalah langkah yang lebih baik dari pada mengisolasi diri secara berlebihan. Serta menerapkan literasi kebahasaan dalam lingkungan keluarga serta masyarakat setempat sangatlah dianjurkan. Agar setiap informasi lisan dan tulisan dapat dipertanggung jawabkan kebenarannya.

Untuk menyikapi berbagai permasalahan dalam kemiskinan bacaan, maka perlulah diselenggarakan\|Workshop Literasi Kebahasaan untuk Orangtua Tentang Bahaya Covid-19 Serta Pengaruhnya Pada Pola Pikir dan Mental Anak yang 23 bertempat tinggal di Linggarjatill. Hal ini dapat mengurangi rasa ketakutan dan kecemasan tentang suatu penyakit yang dapat menyebabkan emosi yang kuat pada orang dewasa dan anak-anak. Oleh karenanya, para orang tua disarankan untuk mengetahui tanda-tanda stres yang dialami anak akibat pandemi COVID-19 ini dengan mengetahaui beberapa istilah yang berkaitan dengan COVID-19.

Istilah-istilah yang berkaitan dengan COVID-19:

1. Social distancing Menurut Centers for Disease Control and Prevention (CDC), arti istilah 'social distancing' atau _pembatasan sosial' adalah menghindari tempat umum, menjauhi keramaian, dan menjaga jarak optimal 2 meter dari orang lain. Dengan adanya jarak, penyebaran penyakit ini diharapkan dapat berkurang.

2. Isolasi dan karantina Kedua istilah terkait virus Corona ini merujuk pada tindakan untuk mencegah penularan virus Corona dari orang yang sudah terpapar virus ini ke orang lain yang belum. Perbedaannya, isolasi memisahkan orang yang sudah sakit dengan orang yang tidak sakit untuk mencegah penyebaran virus Corona, sedangkan karantina memisahkan dan membatasi kegiatan orang yang sudah terpapar virus Corona namun belum menunjukkan gejala. Berbagai pakar menganjurkan untuk melakukan karantina di rumah atau isolasi mandiri selama setidaknya 14 hari. Selama karantina, Anda dianjurkan untuk tinggal di rumah sambil menjalani pola hidup bersih dan sehat, tidak bertemu orang lain, dan menjaga jarak setidaknya 2 meter dari orang-orang yang tinggal serumah.

3. Lockdown Istilah 'lockdown' berarti karantina wilayah, yaitu pembatasan pergerakan penduduk dalam suatu wilayah, termasuk menutup akses masuk dan keluar wilayah. Penutupan jalur keluar masuk serta pembatasan pergerakan penduduk ini dilakukan untuk mengurangi kontaminasi dan penyebaran penyakit COVID-19.

4. Flattening the curve 'Flattening the curve' atau_pelandaian kurva' merupakan istilah di bidang epidemiologi untuk upaya memperlambat penyebaran penyakit menular yang dalam hal ini adalah COVID-19, sehingga fasilitas kesehatan memiliki sumber daya yang memadai bagi para penderita. Pelandaian kurva ini dapat dilakukan dengan social distancing, karantina, dan isolasi. Kurva menggambarkan prediksi jumlah orang yang terinfeksi virus Corona dalam rentang waktu tertentu. Jumlah penderita yang meningkat 
drastis dalam periode yang sangat singkat, misalnya hanya dalam waktu beberapa hari, digambarkan sebagai kurva tinggi yang sempit. Jumlah penderita yang membeludak membuat penanganan tidak bisa dilakukan secara optimal. Hal ini karena jumlah penderita melampaui kemampuan dan kapasitas fasilitas kesehatan, misalnya jumlah tempat tidur dan alat yang tersedia di rumah sakit tidak cukup untuk menangani semua pasien. 24 Kondisi tersebut menyebabkan tingkat kematian menjadi sangat tinggi, tidak hanya pada pasien COVID-19, namun juga pada pasien penyakit lain yang membutuhkan perawatan di rumah sakit. Meskipun jumlah penderitanya sama, namun jika laju pertambahannya lebih lambat (digambarkan oleh kurva yang lebih panjang dan landai), fasilitas kesehatan memiliki kesempatan untuk menangani penderita dengan sarana dan prasarana yang memadai.

5. Pasien dalam pengawasan (PDP) dan orang dalam pemantauan (ODP) PDP dan ODP merupakan definisi yang digunakan untuk mengelompokkan individu berdasarkan:

- Gejala demam dan/atau gangguan pernapasan

- Riwayat perjalanan ke daerah pandemi infeksi virus Corona atau tinggal di daerah tersebut selama 14 hari terakhir sebelum gejala timbul

- Riwayat kontak dengan orang yang terinfeksi atau diduga terinfeksi COVID19 dalam 14 hari terakhir sebelum gejala timbul.

Secara umum, ODP dan PDP bisa dibedakan dari gejala yang dialami. Pada ODP, gejala yang muncul hanya salah satu antara demam atau gangguan pernapasan, seperti batuk, pilek, sakit tenggorokan, dan sesak napas. Sedangkan pada PDP, sudah ada gejala demam maupun gangguan pernapasan. Terhadap PDP, dilakukan rawat inap terisolasi di rumah sakit, pemeriksaan laboratorium, dan pemantauan pada orang lain yang memiliki kontak erat dengan PDP tersebut. Sementara ODP harus menjalani isolasi di rumah dan kondisinya akan dipantau setiap hari selama 2 minggu, menggunakan formulir khusus. Jika kondisi ODP mengalami perburukan dan sudah memenuhi kriteria PDP atau hasil laboratoriumnya positif terinfeksi virus Corona, maka ODP tersebut harus dibawa ke rumah sakit.

6. Orang tanpa gejala (OTG) OTG merupakan istilah yang digunakan untuk orang yang positif terinfeksi virus Corona tetapi tidak mengalami gejala atau gejalanya sangat ringan. OTG tetap harus melakukan isolasi mandiri di rumah selama 14 hari, dipantau melalui telepon oleh petugas pemantau, dan melakukan kontrol setelah 14 hari isolasi mandiri. Selama isolasi mandiri, OTG wajib melakukan pengukuran suhu 2 kali sehari, menggunakan masker, rutin mencuci tangan dengan sabun dan air mengalir atau hand sanitizer, melakukan physical distancing, menerapkan etika batuk, dan tinggal di kamar atau ruangan yang terpisah dari penghuni rumah lainnya. Jika OTG mengalami gejala demam lebih dari $380 \mathrm{C}$, maka OTG wajib menginformasikan hal ini kepada petugas pemantau.

7. Herd immunity Secara harfiah, istilah 'herd immunity' berarti kekebalan kelompok. Herd immunity terhadap suatu penyakit bisa dicapai dengan pemberian vaksin secara meluas atau bila sudah terbentuk kekebalan alami pada sebagian besar orang dalam suatu kelompok setelah mereka terpapar dan sembuh dari penyakit tersebut. 25 Di tengah pandemi COVID-19, sebagian ahli percaya bahwa penularan virus Corona akan menurun atau bahkan berhenti sama sekali bila sudah ada banyak orang yang sembuh dan menjadi kebal terhadap infeksi ini. Meski begitu, hingga saat ini belum ada vaksin untuk COVID-19 dan untuk menunggu hingga tercapai herd immunity secara alami pun sangat berisiko karena penyakit ini dapat berakibat fatal. 


\section{Rangkiang: Lurnal Pengabdian Pada Masyarakat UPSM STKIP PGR/ Sumatera Barat}

ISSN: (2721-2688) Vol. 2 No. 2 (Desember 2020): 49 - 59

8. Pembatasan Sosial Berskala Besar (PSBB) Sesuai dengan Peraturan Menteri Kesehatan yang dikeluarkan untuk penanganan COVID-19, beberapa daerah di Indonesia memberlakukan Pembatasan Sosial Berskala Besar (PSBB). Selama PSBB, pemerintah daerah akan melakukan beberapa hal berikut ini:

- Peliburan sekolah dan tempat kerja

- Pembatasan kegiatan keagamaan

- Pembatasan kegiatan di tempat atau fasilitas umum

- Pembatasan kegiatan sosial budaya

- Pembatasan moda transportasi

- Pembatasan kegiatan lainnya khusus terkait aspek pertahanan dan keamanan.

Aturan peliburan tempat kerja memberikan pengecualian untuk tempat kerja yang memberikan pelayanan pertahanan keamanan, ketertiban umum, kebutuhan pangan, bahan bakar minyak dan gas, pelayanan kesehatan, perekonomian, komunikasi, industri, ekspor impor, distribusi logistik, dan kebutuhan dasar lainnya. Per bulan Juli 2020, Kementrian Kesehatan Republik Indonesia mengganti istilah lama pada COVID-19 seperti ODP, PDP, dan OTG dengan istilah operasional baru, seperti suspek, probable, dan konfirmasi.

\section{SIMPULAN}

Demikianlah beberapa istilah terkait infeksi virus Corona atau COVID-19. Untuk meminimalkan risiko terjangkit penyakit ini, patuhilah anjuran dokter dan pemerintah. Selain mencuci tangan, memakai masker, serta menjalani pola hidup bersih dan sehat, hindari tempat-tempat yang ramai atau berkumpul dengan banyak orang. Pandemi COVID-19 memang mengkhawatirkan, tetapi setiap orang dapat membantu meringkankan kondisi ini dengan melakukan perannya masing-masing serta menyebarkan informasi yang benar sesusi dengan fakta. Inilah beberapa peran pentingnnya literasi kebahasaan yang perlu diketahui dan dikuasi oleh masyarakat, khususnya orang tua untuk terhindar dari bahaya wabah Covid-19 serta dapat berpengaruh pada pembentukan pola pikir dan mental anak-anak. Semoga pembahasan Workshop Literasi Kebahasaan ini dapat bermanfaat bagi pembaca dan peserta.

\section{DAFTAR PUSTAKA}

Dinda Silviana Dewi. 2020. 10 Tanda Anak Tertekan dan Kesehatan Mentalnya Terganggu di Masa Pandemi Coronavirus COVID-19. Kompas.

Graha, C. (2007). Kebersihan Anak di Tangan Orang Tua Paunduan Bagi Orang Tua Untuk Harususilo, Yohanes Enggar. 2020. "6 Tips Jaga Stabilitas Mental Anak Selama PandemiCovid19 https://www.kompas.com/edu/read/2020/04/17/181616871/6-tipsjagastabilitas-mental-anak-selama-pandemi-covid-19?page $=$ all

Kemal, E., Rahmat, W., Tiawati, R. L., \& Dwinitia, S. (2019). PENINGKATAN KEMAMPUAN BERBICARA BAHASA INGGRIS MELALUI TEKNIK MEMBACA BERITA DI SMA DEK PADANG. RANGKIANG: Jurnal Pengabdian Pada Masyarakat, 1(1), 30-34.

Kurniati, Euis. dkk.2020. - Analisis Peran Orangtua dalam Mendampingi Anak Dimasa Pandemi Covid 19\|. Jurnal Pendidikan Anak Usia Dini. Vo. 5. No.1. Memahami Perannya dalam Membantu Keberhasilan. PT Elex Media.

Laila, A., Rahmat, W., \& Samsiarni, S. (2019). PELATIHAN KESOPANAN BERBAHASA SISWA SD BERBASIS KARYA SASTRA DI PERUMAHAN CITRA BUNGO PASANG KELURAHAN SUNGAI TARUNG KECAMATAN KOTO TANGAH PADANG. RANGKIANG: Jurnal Pengabdian Pada Masyarakat, 1(1), 13-24. 
Mahkmudah, Siti. 2016. - Revolusi Mental dalam Mengubah Pola Pikir Tenaga Pendidik Dari Segi Pespektif Islam\|. Jurnal Educatio. Vol. 2. No. 1. Indonesian Institute For Counseling, Education and Therapy.

Murtiningsih, D. (2013). - Peran Orangtua Dalam Kegiatan Bermain Anak Usia Dini (4-6 Tahun) Di Rumah\|. Jurnal Pendidikan Luar Sekolah, 9(2), 1-21. http://ejournal.upi.edu/index.php/pls/article/view/5421

Rahmat, W. (2017). Sinisme Dalam Kaba Sabai Nan Aluih Suatu Bentuk Pentingnya Bahasa Bahasa Ibu: Kajian Pragmatik. Jurnal Curricula, 2.

Rose Mini Agoes Salim melalui siaran langsung dari kanal BNPB Indonesia, Kamis (19/3/2020). Minggu, 13 Mei 2018 17:00 WIB

Yusri, R., Edriati, S., \& Yuhendri, R. (2020). PELATIHAN MICROSOFT OFFICE EXCEL SEBAGAI UPAYA PENINGKATAN KEMAMPUAN MAHASISWA DALAM MENGOLAH DATA. RANGKIANG: Jurnal Pengabdian Pada Masyarakat, 2(1), 32-37.

Yuhendri, R. (2020). EVEKTIFITAS PEMANFAATAN LABORATORIUM BIOLOGI STKIP PGRI SUMATERA BARAT TERHADAP PENINGKATAN PEMAHAMAN SISWA MAN 1 PADANG PARIAMAN. RANGKIANG: Jurnal Pengabdian Pada Masyarakat, 1(2), 96-100. 